\title{
Xyloglucan Oligosaccharides Inhibit Auxin-Stimulated Growth?
}

\author{
キシログルカンオリゴ糖のオーキシン誘導成長阻害作用
}

\author{
Augur, C., Yu, L., Sakai, K., Ogawa, T., Sinaÿ, P., Darvill, A.G., and Albersheim, P. Plant Physiol. (1992) 99, 180-185
}

\section{Key Words: auxin, fucose, oligosaccharin, pea, xyloglucan}

Certain types of oligosaccharide released from plant cell walls exhibit diverse physiological activities. It has been proposed that the regulation of plant growth is one of the major roles of such "oligosaccharins". Albersheim and his coworkers, for the first time, reported that xyloglucan nonasaccharide(XG9, $\mathrm{Glc}_{4} \mathrm{Xyl}_{3} \mathrm{Gal}_{1} \mathrm{Fuc}_{1}$ ) had a capacity of inhibiting auxin-induced elongation of segments of pea stems [York et al., Plant Physiol. (1984) 75, 295-297]. This inhibitory effect of XG9 on plant growth has been further confirmed and analyzed mainly by Fry and his coworkers [ Fry, Trends Glycosci. Glycotechnol. (1992) 4, 179-189]. In the present paper, Albersheim et al., after a long interval, addressed this issue again. They attempted to clarify the structural features required for xyloglucan oligosaccharides to inhibit plant growth by examining the effect of different oligosaccharides on auxin-induced elongation of pea segments.

A xyloglucan undecasaccharide(XG11) containing two fucosyl-galactosyl side chains was purified from cellulasetreated sycamore xyloglucan and tested for its capacity to inhibit growth. XG11 inhibited elongation of pea stem segments, induced by 2,4-dichlorophenoxyacetic acid(2,4-D, a synthetic auxin), to a greater extent than did XG9. The removal of the xylosyl residue farthest from the reducing end of XG9 by a specific $\alpha$-xylosidase did not influence its growth-inhibiting capacity. The alditol derivative of XG9 inhibited 2,4-Dinduced elongation as XG9 did. The experiments using chemically synthesized XG9 and xyloglucan pentasaccharide confirmed that these oligosaccharides and not an unidentified contaminant were responsible for the growth inhibition. From these results as well as the data presented by Fry et al., it is concluded that the terminal $\alpha$-L-fucosyl residues of xyloglucan oligosaccharides are crucial in determining their growthinhibiting capacity.

Thus, it became clear that xyloglucan oligosaccharides with a certain structure inhibited auxin-induced elongation of pea stem segments under certain conditions. However, all of the above-mentioned data were obtained in the same experimental system, which involved long-term incubation(16$18 \mathrm{hr}$ ) of pea segments in a solution containing 2,4-D and sucrose. Such a growth-inhibiting effect of XG9 was not always detected in other species or in other experimental systems, nor did XG9 inhibit auxin-induced cell wall loosening
ある種の植物細胞壁起源のオリゴ糖は多彩な生理活性を示 す。これら”オリゴサッカリン”の主要な作用の一つとして、 植物の成長の調節があげられている。Albersheimらは、キシロ グルカン9糖(XG9)がエンドウ茎切片のオーキシン誘導伸長成長 を阻害する能力を持つことを最初に報告した[York et al., Plant Physiol. (1984) 75, 295-297]。このようなXG9の成長阻害作用 は、その後おもにFryらによって確認され、研究されてきた[Fry， Trends Glycosci. Glycotechnol. (1992) 4, 179-189]。本論文で Albersheimらは、久しぶりにこの現象を取り上げ、エンドウ切 片のオーキシン誘導伸長成長に対する様々なキシログルカンオ リゴ糖の作用を調べることによって、植物の成長を阻害するの に必要なオリゴ糖の構造上の特徵を明らかにしようと試みた。

彼らは、シカモアカエデのキシログルカンのセルラーゼ分 解産物より、フコース・ガラクトース側鎖 2 個を持つキシログル カン11糖(XG11)を抽出、精製し、それが成長阻害作用を持つか 調べた。XG11は、エンドウ茎切片の2,4-ジクロロフェノキシ酢 酸(合成オーキシンの1種、2,4-D)によって誘導される伸長成長を XG9より強く阻害した。XG9の最も非還元側に位置するキシ ロース側鎖をキシログルカンオリゴ糖に特異的な $\alpha$-キシロシ ダーゼで除去しても、成長阻害作用には影響しなかった。XG9 の糖アルコール誘導体もXG9 と同程度の成長阻害を示した。化 学的に合成したXG9やキシログルカン5糖(XG5)を用いた実験よ り、このような成長阻害はオリゴ糖自身の作用の結果であり、 未確認の混入物質の働きによるのではないことが分かった。本 論文で示された実験データと先にFryらによって報告された結果 を合わせて、キシログルカン側鎖末端に位置する $\alpha$-L-フコース 残基が、キシログルカンオリゴ糖が成長阻害作用を示す上で重 要な働きをしていると結論された。

このように、ある種の条件下では、特定の構造を持つキシ ログルカンオリゴ糖がエンドウ茎切片のオーキシン誘導伸長成 長を阻害することが明かとなった。しかしながら、以上の結果 は、2,4-D及びスクロースを含む溶液中での長時間(16-18時間)の 成長という共通の条件下で得られたものである。XG9の成長阻 害作用はエンドウ以外の種やこの実験条件以外では必ずしも認 められないし、エンドウ茎切片においてもXG9はオーキシンに よる細胞壁のゆるみに影響しなかった[Hoson and Masuda, Plant 
in pea stem segments[Hoson and Masuda, Plant Cell Physiol. (1991) 32, 777-782]. It will be necessary to test the generality of the growth-inhibiting effect of xyloglucan oligosaccharides as well as to study the mechanism by which they exhibit such an effect, to evaluate the role of oligosaccharins in the regulation of plant growth.

\section{Reported by Takayuki Hoson}

Department of Biology, Faculty of Science,

Osaka City University,

Osaka 558, Japan
Cell Physiol. (1991) 32, 777-782]。植物の成長調節におけるオリ ゴサッカリンの役割を正しく評価する為には、キシログルカン オリゴ糖による成長阻害機構を解析すると共に、成長阻害作用 が広く一般的に認められるか調べる必要があろう。

\section{大阪市立大学・理学部 ·生物学科}

保尊 隆享 